\title{
Aplikasi Teknologi Proliga (Produksi Lipat Ganda) untuk Penanaman Beberapa Varietas Unggul Cabai Merah Keriting (Capsicum annuum L.) pada Lahan Marginal
}

\author{
Murdhiani ${ }^{1}$ Maria Heviyanti ${ }^{1}$, Silvia Anzitha ${ }^{2}$ dan Rina Maharany ${ }^{3}$ \\ ${ }^{1}$ Program Studi Agroteknologi, Fakultas Pertanian, Universitas Samudra \\ ${ }^{2}$ Program Studi Agribisnis, Fakultas Pertanian, Universitas Samudra \\ ${ }^{3}$ Budidaya Perkebunan STIPAP \\ Jalan. Prof. Dr. Syarief Thayeb, Meurandeh, Langsa-Aceh, 24416 \\ *Alamat korespondensi: mariah@unsam.ac.id
}

\begin{tabular}{lrc}
\hline \multicolumn{2}{c}{ INFO ARTIKEL } & ABSTRACT/ABSTRAK \\
\hline Diterima: & $22-07-2021$ & \\
Direvisi: & $05-08-2021$ & Application of Multiple Production Technology for Planting Several High- \\
Dipublikasi:11-08-2021 & Yielding Varieties of Curly Red Chili (Capsicum annuum L.) on Marginal \\
& & Land
\end{tabular}

Keywords:

Double

Production,

Kastilo, Lado,

Taro, PM 999

Kata Kunci:

Kastilo, Lado,

PM 999,

Produksi lipat

ganda, Taro
Red chili (Capsicum annum L.) belongs to the Solanaceae family of plants and is one of the most important vegetable crops in Indonesia. Multiple production technology (Proliga) is a technology package that aims to double chili production both during on season and off season. This study aimed to determine the level of adaptation, growth and development as well as production of several red chili varieties cultivated on marginal land through the application of Proliga technology. In this study five proliga technology component were applied namely the use of high yielding varieties, healthy nurseries by pruning, increasing plant population with a two-one zig zag planting system, tillage and fertilization, and controlling plant pest organism (OPT). The high yielding varieties of curly red chili that was tested in this study were Lado F1, PM 999 F1, Taro F1 dan Kastilo F1 varieties. The design used in this study was a Randomized Block Design (RAK) with four replications. The result showed that Lado F1, PM 999 F1, Taro F1 dan Kastilo F1varieties were no significant effect on the parameters plant height at 2 and 4 WAP, flowering age and number of branches at 5 WAP, however significantly affected the parameters of the number of branches at 4 MST. The highest number of branches was found in treatment V2 (Variety PM 999 F1), which was 57.50 branches. The highest production of red chili per plot was also found in treatment V2 (Variety PM 999 F1) with fruit weight per plot of $267.88 \mathrm{~g}$. Based on the results, we concluded that of the four curly red chilies varieties which was planted on the marginal land by using proliga technology, the PM 999 F1 variety is a high-yielding variety of curly red chili that is able to adapt on marginal land.

Cabai merah (Capsicum annuum L.) termasuk ke dalam keluarga tanaman Solanaceae merupakan salah satu tanaman sayuran penting di Indonesia. Teknologi Proliga (Produksi Lipat Ganda) merupakan suatu paket teknologi yang tujuannya melipatgandakan produksi cabai baik pada saat on season maupun saat off season. Penelitian bertujuan untuk mengetahui tingkat adaptasi, pertumbuhan dan perkembangan serta produksi dari beberapa varietas cabai merah yang dibudidayakan pada lahan marginal melalui penerapan teknologi Proliga. Penelitian ini menerapkan lima komponen 
teknologi proliga yaitu penggunaan varietas unggul, persemaian sehat dengan pemangkasan pucuk, meningkatkan populasi tanaman dengan sistem tanam dua satu zig zag, pengolahan tanah dan pemupukan, serta pengendalian organisme pengganggu tanaman (OPT). Varietas-varietas unggul cabai merah keriting yang digunakan dalam penelitian ini adalah varietas Lado F1, PM 999 F1, Taro F1 dan Kastilo F1. Penelitian ini menggunakan Rancangan Acak Kelompok (RAK) dengan empat ulangan. Hasil penelitian menunjukkan bahwa varietas Lado F1, PM 999 F1, Taro F1 dan Kastilo F1 berpengaruh tidak nyata terhadap parameter tinggi tanaman umur 2 dan 4 minggu setelah tanam (MST), umur berbunga dan jumlah cabang umur 5 MST, akan tetapi berpengaruh nyata pada parameter jumlah cabang umur 4 MST. Jumlah cabang terbanyak terdapat pada perlakuan $\mathrm{V}_{2}$ (Varietas PM 999 F1) yaitu 57,50 cabang. Produksi cabai merah per plot plot tertinggi terdapat pada perlakuan $\mathrm{V}_{2}$ (Varietas PM 999 F1) dengan berat buah per plot yaitu 267,88 g. Berdasarkan hasil penelitian dapat disimpulkan bahwa dari empat varietas unggul cabai merah yang di tanam pada lahan marginal dengan menerapkan teknologi proliga, varietas PM 999 F1 merupakan varietas unggul cabai merah keriting yang mampu beradaptasi pada lahan marginal.

\section{PENDAHULUAN}

Cabai merah (Capsicum annuum L.) merupakan salah satu tanaman sayuran penting di Indonesia. Cabai merah selain digunakan sebagai bahan masakan, digunakan juga sebagai obat-obatan. Hingga saat ini cabai merah merupakan komoditas yang strategis sehingga permintaan terhadap cabai merah tidak pernah turun. Secara umum cabai merah memiliki banyak kandungan gizi dan vitamin, diantaranya kalori, protein, lemak, kabohidarat, kalsium, vitamin $\mathrm{A}, \mathrm{B} 1$, dan vitamin $\mathrm{C}$ (Piay dkk., 2010). Menurut Shofiatun dkk. (2017), salah satu komoditas sayuran yang sangat digemari oleh sebagian besar masyarakat adalah cabai merah. Cabai merah merupakan bumbu masak yang memiliki aroma khas dan berasa pedas sehingga akan membangkitkan selera makan. Oleh karena itu permintaan akan cabai merah terus meningkat seiring dengan peningkatan jumlah penduduk. Meningkatnya permintaan akan cabai merah pada akhirnya akan berpengaruh terhadap harga cabai merah, pendapatan, dan fungsi barang itu sendiri. Berdasarkan data Badan penelitian dan pengembangan pertanian (Balitbangtan) (2019), rata-rata produksi cabai merah di Indonesia hingga saat ini hanya berkisar 10,2 ton/Ha.

Kendala yang dihadapi dalam melakukan budidaya tanaman cabai saat ini berkaitan erat dengan permasalahan teknik budidaya, kualitas benih, serangan hama dan penyakit tanaman, varietas cabai yang digunakan masih rendah, serta terjadinya perubahan iklim yang tidak menentu (Setyawan dkk., 2020). Faktor lainnya yang menjadi kendala dalam budidaya tanaman cabai merah adalah ketersedian lahan. Lahan memiliki kontribusi yang besar dalam budidaya tanaman cabai merah karena besar kecilnya produksi pertanian dapat dipengaruhi luas sempitnya lahan pertanian yang digunakan. Oleh karenanya lahan pertanian dapat dikatakan sebagai pabriknya hasil pertanian. Akan tetapi, peningkatan jumlah penduduk dan alih fungsi lahan menyebabkan semakin berkurangnya ketersedian lahan usahatani (Pranata \& Damayanti, 2016).

Lahan menjadi salah satu satu agroekosistem yang perlu diperhatikan dalam budidaya tanaman cabai merah. Hal ini penting karena setiap varietas cabai merah memiliki kemampuan adaptasi yang berbeda, yang pada akhirnya akan berpengaruh terhadap hasil produksi. Cabai merah selama ini hanya dibudidayakan pada lahan-lahan optimal saja, sehingga lahan-lahan sub-optimal jadi tidak terperhatikan. Kenyataannya lahan-lahan suboptimal (marginal) juga dapat memberikan produksi yang maksimal juga (Litbang, 2019). Kurangnya prioritas terhadap lahan-lahan marginal terhadap pengembangan teknologi menyebabkan lahan ini menjadi tidak produktif. Lahan-lahan marginal pada umumnya terletak di daerah-daerah terpencil dengan minimnya suplai input produksi dan transportasi yang memadai. Berbagai inovasi 
teknologi telah dikembangkan untuk mengatasi permasalahan ini, akan tetapi jika tidak dideseminasikan dan diterapkan maka menjadi tidak bermanfaat (Iriani \& Wulanjari, 2012). Balitbangtan baru-baru ini memperkenalkan teknologi terbaru yang dapat meningkatkan produksi cabai. Teknologi tersebut hingga saat ini masih terus didesiminasikan untuk mencapai swasembada. Teknologi tersebut dikenal dengan Teknologi Proliga (Produksi Lipat Ganda). Teknologi ini dapat diterapkan baik pada lahan optimal maupun marginal (sub-optimal) (Bardono, 2018). Proliga merupakan suatu paket teknologi yang tujuannya melipat gandakan produksi cabai baik pada saat on season maupun saat off season. Paket teknologi Proliga cabai yang diperkenalkan oleh Balitbangtan meliputi penggunaan varietas unggul, persemaian sehat, peningkatan jumlah populasi tanaman, hara yang sesuai, dan pengendalian OPT berdasarkan konsep PHT (BPTP Jatim, 2019).

Varietas unggul merupakan galur hasil pemuliaan tanaman yang memiliki beberapa sifat keunggulan dibandingkan dengan varietas lainnya. Sifat keunggulan tersebut diantaranya potensi hasil tinggi, tahan terhadap hama dan penyakit, toleran terhadap cekaman lingkungan, kualitas produksi baik, dan sifat-sifat lainnya. Kemampuan adaptasi setiap varietas terhadap agroekosistem tempat varietas ditanam merupakan salah satu hal yang perlu diperhatikan dalam penggunaan varietas unggul (Ellya, 2018). Input-input produksi yang dapat mempengaruhi produksi cabai merah adalah ketersediaan lahan, benih bermutu, pemupukan yang seimbang, penggunaan pestisida secara tepat, dan ketersediaan tenaga kerja. Oleh karena itu memperhatikan input-input produksi tersebut sangat penting dilakukan agar dapat meningkatkan produksi cabai merah pada setiap kegiatan usahatani yang dilakukan (Andayani, 2016).

Berdasarkan uraian di atas, maka penerapan teknologi Proliga dan pengujian terhadap varietasvarietas unggul tanaman cabai perlu dilakukan untuk mendapatkan varietas tanaman cabai yang unggul dan tahan kekeringan serta berproduksi tinggi. Penelitian ini diharapkan dapat membantu petani dalam menerapkan teknologi Proliga dan menentukan varietas cabai merah unggul yang akan digunakan dalam kegiatan usahataninya. Tujuan penelitian adalah untuk mengkaji tingkat pertumbuhan, perkembangan, dan produksi tujuh varietas unggul cabai merah keriting yang dibudidayakan pada lahan kering (lahan marginal) dengan penerapan teknologi Proliga. Urgensi penelitian adalah untuk memperoleh varietas unggul tanaman cabai yang dapat beradaptasi dan dibudidayakan di lahan dengan kondisi lingkungan yang kering (pada lahan marginal) dengan penerapan teknologi proliga. Hasil penelitian ini pada akhirnya dapat dijadikan rekomendasi bagi petani cabai merah untuk melakukan penanaman pada lahan marginal dengan teknologi Proliga.

\section{BAHAN DAN METODE}

\section{Waktu dan Tempat Penelitian}

Penelitian dimulai pada bulan Juni 2020 hingga Desember 2020. Penelitian ini dilaksanakan di Kebun Percobaan Pertanian Program Studi Agroteknologi, Fakultas Pertanian, Universitas Samudra.

\section{Rancangan Penelitian}

Penelitian menggunakan Rancangan Acak Kelompok (RAK) yang terdiri dari empat perlakuan dan empat ulangan, sehingga diperoleh delapan unit percobaan. Empat varietas unggul cabe merah keriting yang di uji yaitu varietas Lado F1, PM 999 F1, Taro F1 dan Kastilo F1.

\section{Pelaksanaan Penelitian}

Media persemaian menggunakan gabungan antara pupuk kotoran hewan, pasir, dan top soil dengan rasio $1: 1: 1$ dan dimasukkan ke dalam bak persemaian. Tempat persemaian yang telah di isi media tanam dibasahi dengan air, kemudian biji cabai disemai. Setelah biji cabai tumbuh, pada hari kesebelas bibit cabai dipindahkan ke polybag yang sebelumnya telah di isi media tanam. Lahan dibersihkan dari berbagai gulma hingga lahan menjadi bersih dan siap untuk dilakukan pengolahan tanah yang dilakukan sebanyak dua kali pengolahan. Setelah selesai mengolah tanah, kegiatan berikutnya adalah pembuatan plot dengan ukuran panjang $5 \mathrm{~m}$, lebar $110 \mathrm{~cm}$, tinggi $30 \mathrm{~cm}$ lebar parit $44 \mathrm{~cm}$. Setelah bedengan jadi diberi pupuk kandang sebanyak 20 ton/ha, serta disiram air secukupnya dan segera dipasang mulsa plastik hitam perak. Plot penelitan dibuat sesuai rencana penelitian yaitu 16 plot.

Pada hari ke 6-7 hari setelah bedengan selesai kemudian dipasang mulsa plastik hitam perak, yangd ilanjutkan dengan kegiatan pembuatan lubang pada mulsa plastik satu hari sebelum dilakukan penanaman. Pada saat benih berumur 2 minggu setelah tanam (MST), benih ditanam pada bedengan 
dengan jarak tanam $70 \mathrm{~cm}$ x $50 \mathrm{~cm}$. Pemupukan tanaman cabai menggunakan dosis yaitu pupuk dasar 100-120 kg/ha (pupuk N), $80 \mathrm{~kg} / \mathrm{ha}$ (pupuk $\mathrm{P}_{2} \mathrm{O}_{5}$ ), dan $100-120 \mathrm{~kg} / \mathrm{ha}$ (pupuk $\mathrm{K}_{2} \mathrm{O}$ ) serta pupuk susulan diberikan pada umur 10-15 hari, 30-35 hari, dan 40-50 hari dengan dosis sepertiga dari 270-330 $\mathrm{kg} / \mathrm{ha}$ (pupuk N). Penyulaman bagi tanaman yang tumbuh abnormal dilakukan dilakukan 7-14 hari setelah penanaman. Pengendalian hama, gulma dan penyakit merupakan kegiatan pemeliharaan yang dilakukan sesuai kondisi yang terjadi pada saat penelitian. Pemakaian pestisida dalam kegiatan pemeliharaan tanaman merupakan alternatif yang digunakan jika secara mekanis sudah tidak dapat dikendalikan. Pengamatan yang diukur di antaranya tinggi tanaman pada saat tanaman berumur 2 MST dan 4 MST, jumlah cabang pada saat tanaman berumur 5 MST dan 7 MST, umur berbunga dan hasil panen. Data yang diperoleh diuji dengan uji sidik ragam yang dapat menunjukkan adanya perbedaan yang nyata pada beberapa varietas. Jika terdapat perbedaan maka dilanjutkan dengan uji BNT 5\%.

\section{HASIL DAN PEMBAHASAN}

\section{Tinggi Tanaman}

Data pengamatan dan analisis sidik ragam terhadap parameter tinggi tanaman cabai merah keriting umur 2 MST dan 4 MST disajikan pada Tabel 1. Hasil analisis sidik ragam menunjukkan bahwa penggunaan varietas unggul dengan teknik Proliga di lahan marginal berpengaruh tidak nyata terhadap parameter tinggi tanaman cabai merah keriting umur 2 MST dan 4 MST. Hasil uji beda ratarata penggunaan varietas unggul dengan teknik Proliga di lahan marginal terhadap tinggi tanaman cabai merah keriting umur 2 MST dan 4 MST dapat dilihat pada Tabel 1.

\section{Umur Berbunga}

Hasil analisis sidik ragam menunjukkan bahwa penggunaan varietas unggul dengan teknik Proliga di lahan marginal berpengaruh tidak nyata terhadap parameter umur berbunga tanaman cabai merah keriting. Hasil uji beda rata-rata penggunaan varietas unggul dengan teknik Proliga di lahan marginal terhadap umur berbunga dapat dilihat pada Tabel 2.
Tabel 1. Hasil uji beda rataan penggunaan varietas unggul dengan teknik Proliga di lahan marginal terhadap tinggi tanaman cabai merah keriting umur 2 MST dan 4 MST

\begin{tabular}{l|c}
\hline \multicolumn{1}{c}{ Varietas (V) } & Tinggi tanaman (cm) \\
\hline \multicolumn{2}{|c}{ 2 MST } \\
\hline $\mathrm{V}_{1}$ (Lado F1) & 18,12 \\
$\mathrm{~V}_{2}$ (PM 999 F1) & 22,13 \\
$\mathrm{~V}_{3}$ (Taro F1) & 19,79 \\
$\mathrm{~V}_{4}$ (Kastilo F1) & 20,71 \\
\hline \multicolumn{2}{c}{} \\
\hline $\mathrm{V}_{1}$ (Lado F1) & 25,79 \\
$\mathrm{~V}_{2}$ (PM 999 F1) & 33,24 \\
$\mathrm{~V}_{3}$ (Taro F1) & 25,52 \\
$\mathrm{~V}_{4}$ (Kastilo F1) & 28,94 \\
\hline
\end{tabular}

Tabel 2. Hasil uji beda rataan penggunaan varietas unggul dengan teknik Proliga di lahan marginal terhadap umur berbunga cabai merah keriting

\begin{tabular}{l|c}
\hline \multicolumn{1}{c|}{ Varietas (V) } & Umur berbunga (hari) \\
\hline $\mathrm{V}_{1}$ (Lado F1) & 34,17 \\
$\mathrm{~V}_{2}$ (PM 999 F1) & 34,75 \\
$\mathrm{~V}_{3}$ (Taro F1) & 34,67 \\
$\mathrm{~V}_{4}$ (Kastilo F1) & 35,25 \\
\hline
\end{tabular}

Tabel 3. Hasil uji beda rataan penggunaan varietas unggul dengan teknik Proliga di lahan marginal terhadap jumlah cabang cabai merah keriting umur 5 MST dan 7 MST

\begin{tabular}{l|c}
\hline \multicolumn{1}{c|}{ Varietas (V) } & Jumlah cabang (cabang) \\
\hline \multicolumn{2}{|c}{5 MST } \\
\hline V $_{1}$ (Lado F1) & 23,75 \\
V $_{2}$ (PM 999 F1) & 23,17 \\
V $_{3}$ (Taro F1) & 18,50 \\
V $_{4}$ (Kastilo F1) & 17,67 \\
\hline \multicolumn{2}{|c}{7 MST } \\
\hline V $_{1}$ (Lado F1) & $49,58 \mathrm{~b}$ \\
V $_{2}$ (PM 999 F1) & $57,50 \mathrm{~d}$ \\
V $_{3}$ (Taro F1) & $45,75 \mathrm{a}$ \\
$\mathrm{V}_{4}$ (Kastilo F1) & $50,25 \mathrm{c}$ \\
\hline
\end{tabular}

Keterangan: Angka yang diikuti oleh huruf yang tidak sama pada baris dan kolom yang sama menunjukkan berbeda nyata pada tarafuji BNT 5\%.

\section{Jumlah Cabang}

Jumlah cabang merupakan gambaran pertumbuhan pada tanaman. Pengukuran dilakukan setiap minggunya yaitu umur 5 MST dan 7 MST. Berdasarkan hasil analisis sidik ragam menunjukkan 
bahwa penggunaan varietas unggul dengan teknik Proliga di lahan marginal berpengaruh tidak nyata pada umur 5 MST dan berpengaruh nyata terhadap jumlah cabang umur 7 MST. Penggunaan varietas unggul dengan teknik Proliga di lahan marginal terhadappengamatan jumlah cabang cabai merah keriting dapat dilihat pada Tabel 3.

Tabel 3 menunjukkan bahwa penggunaan varietas unggul dengan teknik Proliga di lahan marginal terhadap parameter jumlah cabang umur 7 MST yang paling banyak terdapat pada perlakuan $\mathrm{V}_{2}$ yaitu varietas PM $999 \mathrm{~F} 1$. Jumlah cabang terbanyak tanaman cabai merah keriting pada perlakuan $\mathrm{V}_{2}$ adalah 57,50 cabang. Sementara itu, jumlah cabang terendah tanaman cabai merah keriting pada perlakuan $\mathrm{V}_{3}$ (Taro F1) adalah 45,75 cabang.

Tingginya cabang produktif per tanaman pada varietas PM $999 \mathrm{~F} 1$ terkait dengan jenis varietas yang memiliki respon yang berbeda terhadap jumlah cabang produktif yang dihasilkan. Hasil penelitian ini juga sesuai dengan penelitian Hayati (2012) yang menyatakan bahwa selain pemupukan, penggunaan varietas juga merupakan faktor yang sangat penting dalam meningkatkan produksi cabai. Varietas terdiri dari sejumlah genotipe yang berbeda di mana masing-masing genotipe mempunyai kemampuan menyesuaikan diri terhadap lingkungan. Setiap varietas memiliki perbedaan genetik yang dapat mempengaruhi pertumbuhan dan hasil serta kemampuan adaptasi suatu varietas berbeda-beda (Hayati dkk., 2012).

\section{Produksi Buah Per Plot}

Berdasarkan hasil analisis sidik ragam menunjukkan bahwa penggunaan varietas unggul dengan teknik Proliga di lahan marginal di lahan marginal berpengaruhnyata terhadap produksi buah per plot. Penggunaan varietas unggul dengan teknik Proliga di lahan marginalterhadappengamatan produksi buah per plot cabai merah keriting dapat dilihat pada Tabel 4 .

Tabel 4 menunjukkan bahwa penggunaan varietas unggul dengan teknik Proliga di lahan marginal terhadap parameter produksi buah per plot yang paling banyak terdapat pada perlakuan $\mathrm{V}_{2}$ yaitu varietas PM 999 F1. Produksi buah per plot tertinggi tanaman cabai merah keriting pada perlakuan $\mathrm{V}_{2}$ adalah 267,88 gram. Sedangkan produksi buah per plot terendah tanaman cabai merah keriting pada perlakuan V3 adalah 199,19 gram.
Tabel 4. Hasil uji beda rataan penggunaan varietas unggul dengan teknik proliga di lahan marginal terhadap produksi buah per plot cabai merah keriting

\begin{tabular}{l|c}
\hline \multicolumn{1}{c|}{ Varietas $(\mathrm{V})$} & Produksi buah per plot $(\mathrm{g})$ \\
\hline $\mathrm{V}_{1}$ (Lado F1) & $219,75 \mathrm{c}$ \\
$\mathrm{V}_{2}$ (PM 999 F1) & $267,88 \mathrm{~d}$ \\
$\mathrm{~V}_{3}$ (Taro F1) & $199,19 \mathrm{a}$ \\
$\mathrm{V}_{4}$ (Kastilo F1) & $210,89 \mathrm{~b}$ \\
\hline
\end{tabular}

Keterangan: Angka yang diikuti oleh huruf yang tidak sama pada baris dan kolom yang sama menunjukkan berbeda nyata pada taraf uji 5\% dengan menggunakan uji BNT.

Tingginya produksi berat buah per plot pada varietas PM 999 F1 karena banyaknya jumlah cabang dibandingkan varietas yang lainnya. Disamping itu varietas PM 999 F1 mampu beradaptasi dengan sangat baik, dan tahan terhadap penyakit. Menurut Setyawan dkk. (2020) cabai keriting PM 999 F1 merupakan cabai yang dikenal memiliki kemampuan adaptasi yang sangat baik, vigor tahan terhadap penyakit dan juga berpotensi menghasilkan produksi yang tinggi. Varietas tersebut sangat cocok ditanam di daerah dataran rendah hingga menengah. Selain varietas unggul, kepadatan populasi tanaman juga akan mempengaruhi produksi cabai. Biasanya dalam 1 ha, petani akan menanam 20.000 tanaman cabai. Pada proliga populasi tanaman cabai ditingkatkan menjadi 30.000 tanaman/ha. Agar tercapai jumlah 30.000 tanaman/ha maka dilakukan penanaman dengan pola 2:1 zig-zag. Pada 1 lubang ditanaman 2 tanaman kemudian lubang berikutnya 1 tanaman. Metode tanaman zig-zag ini bertujuan agar cahaya matahari tidak akan terhalang dan sirkulasi udara tidak terganggu (Balitbangtan, 2020).

\section{SIMPULAN}

Berdasarkan data-data hasil pengujian dapat disimpulkan bahwa penggunaan varietas unggul dengan teknik Proliga di lahan marginal terhadap parameter tinggi tanaman umur 2 MST dan 4 MST, umur berbunga dan jumlah cabang umur 5 MST berpengaruh tidak nyata, tetapi untuk parameter jumlah cabang umur 7 MST dan produksi buah per plot memperlihatkan pengaruh yang nyata. Jumlah cabang umur 7 MST yang terbanyak terdapat pada perlakuan $V_{2}$ (Varietas PM 999 F1) adalah 57,50 cabang dan produksi berat buah per plot tertinggi juga terdapat pada perlakuan $V_{2}$ yaitu 267,88 g. 


\section{UCAPAN TERIMA KASIH}

Ucapan terima kasih Penulis sampaikan kepada Universitas Samudra yang telah memberikan dana penelitian ini serta kepada semua pihak yang tealh terlibat di dalam kegiatan penelitian ini.

\section{DAFTAR PUSTAKA}

Andayani, SA. 2016. Faktor-faktor yang mempengaruhi produksi cabai merah. Mimbar Agribisnis. 1(3):261-268.

Bardono, S. 2018. Berkat Proliga Produksi Cabai Berlipat Ganda. Inovasi Pertanian. Tersedia online pada http://technologyindonesia.com/pertanian-dan-

pangan/inovasi-pertanian/berkat-proligaproduksi-cabai-berlipat-ganda/. Diakses Januari 2021.

Balitbangtan. 2019. Info Teknologi: Teknologi Proliga Cabai di balitbangtan sukses untuk lahannya.

BPTP Jatim. 2019.Teknologi Proliga Cabai Balitbangtan Diminati dan Mulai Menuai Hasil.

Ellya. 2018. Panen Cabai Melimpah dengan Teknologi Proliga Cabai Balitbangtan. Tersedia online pada http://beritajateng.net/panen-cabai-melimpahdengan-teknologi-proliga-cabai-balitbangtan/. Diakses Januari 2021.

Gunadi, G. 2002. Teknologi Pemanfaatan Lahan Marginal Kawasan Pesisir. Jurnal Teknologi Lingkungan. 3:232-236.

Hayati, E, T Mahmud, dan F Riza. 2012. Pengaruh jenis pupuk organik dan varietas terhadap pertumbuhan dan hasil tanaman cabai (Capsicum annum L.). Jurnal Floratek. 7:173181.

Iriani, E, dan ME Wulanjari. 2012. Pengembangan produksi cabai merah melalui pendekatan standar operasional prosedur pada musim kemarau di lahan kering Kabupaten Blora. Jurnal Litbang Provinsi Jawa Tengah. 10(1):59-70.

Litbang. 2019. Teknologi Proliga Cabai Balitbangtan. Tersedia online pada https://www.litbang.pertanian.go.id. Diakses Feburari 2021.

Litbang. 2019. Varietas Unggul.Tersedia online pada https://www.litbang.pertanian.go.id. Diakses Februari 2021.

Piay, SS, A Tyasdjaja, Y Ermawati, dan FRP Hantoro. 2010. Budidaya dan Pascapanen Cabai Merah (Capsicum annuum L.). Badan Penelitian dan Pengembangan Pertanian Balai Pengkajian Teknologi Pertanian Jawa Tengah. Ungaran.

Pranata, WG, dan L Damayanti. 2016. Faktor-faktor yang mempengaruhi produksi usahatani cabai merah kriting di Desa Bulupountu Jaya Kecamatan Sigi Biromaru Kabupaten Sigi. Jurnal Agroland. 23(1): 11-19.

Shofiatun, D Hastuti, dan R Prabowo. 2017. Analisis permintaan cabai merah keriting (Capsicum annum L.) di Kota Semarang. Mediagro. 13(1): 79-91.

Setyawan, AB, P Setyastuty, dan Sukidjo. 2020. Pertumbuhan dan hasil benih lima varietas cabai merah Capsicum annum, L. di dataran menengah. Jurnal Vegetalika. 3(2): 1-11. 